Original article

\title{
Organic matter distribution and nutrient fluxes within a sweet chestnut (Castanea sativa Mill.) stand of the Sierra de Gata, Spain
}

\author{
Ignacio Santa Regina* \\ IRNA-CSIC, Cordel de Merinas 40-52, Apdo 257, 37071 Salamanca, Spain
}

(Received 27 September 1999; accepted 25 May 2000)

\begin{abstract}
The aboveground biomass, litterfall and its accumulation, litter weight loss due to decomposition and nutrient pools in relation to soil properties were analyzed in a Castanea sativa Mill. stand in order to better understand the recycling of elements associated with the turnover of organic matter. The aboveground biomass and the nutrient content were estimated by harvesting eight trees. In order to establish regression equations the best fit was obtained by applying the allometric method $Y=a X^{b}$ ( $Y=$ total aboveground biomass, $X$ is $\mathrm{DBH})$. The highest concentration of the elements was found in the foliage and decreased in the following order: leaves $>$ branches $>$ trunk. The elements most concentrated in the leaves were N, Mg, P and K. These concentrations fluctuated consistently throughout the phenological cycle. The leaves are the main vector of the potential return of all nutrients to the holorganic horizon, followed by flowers for $\mathrm{N}, \mathrm{P}$ and $\mathrm{Mg}$, branches for $\mathrm{Ca}$ and fruits for $\mathrm{K}$. Considering both total litter and leaves separately, higher $K$ (Jenny's decomposition constant) and Ko (Olson's decomposition constant) values were estimated for leaves alone than for total litter. At the end of decomposition period the loss of dry matter was $47 \%$. The decomposition rates of leaves confined to litterbags for the first year were lower than those obtained under natural conditions ( $22 \%$ in the litterbags, $K=0.44, K \mathrm{o}=0.39$ under natural conditions).
\end{abstract}

aboveground biomass / litterfall / nutrient return / litterbags experiment / forest ecosystem / Castanea sativa

Résumé - Distribution de la matière organique et flux de nutriments dans un peuplement de châtaigniers (Castanea sativa Mill.) de la Sierra de Gata (Espagne). Pour mieux connaître le recyclage des bioéléments associés à la matière organique, on a estimé la biomasse aérienne, la production et accumulation de litière et la perte de poids à partir de sa décomposition en relation aux propriétés du sol dans une parcelle de Castanea sativa Mill. La biomasse aérienne a été estimée par récolte et pesée de huit arbres. Les meilleures corrélations ont été trouvées avec des régressions allométriques de type : $Y=a X^{b}(Y=$ biomasse, $X=$ diamètre tronc à $1.30 \mathrm{~m}$ ). La concentration d'éléments la plus élevée a été trouvée dans les feuilles et décroît dans l'ordre suivant : feuilles $>$ branches $>$ tronc. Les éléments les plus concentrés dans les feuilles sont $\mathrm{N}, \mathrm{Mg}, \mathrm{P}$ et $\mathrm{K}$. Tout au long du cycle phénologique, on a observé une variation des concentrations. Les feuilles sont le principal vecteur du retour potentiel de tous les nutriments à un horizon holorganique, suivies par les inflorescences pour $\mathrm{N}, \mathrm{P}$ et $\mathrm{Mg}$, les branches pour Ca et les fruits pour K. Les index de décomposition de Jenny $(K)$ et Olson $(K o)$ ont été estimés pour les feuilles seules et pour la litière totale. À la fin de la période de décomposition, la perte de poids de la matière organique atteint $47 \%$. L'index de décomposition des feuilles dans les sacs à la fin de la première année sont plus faibles que ceux obtenus en conditions naturelles ( $22 \%$ dans les sacs, $K=0,44, K_{0}=0,39$ en conditions naturelles).

biomasse aérienne / chute de litière / retour de nutriments / écosystème forestier / Castanea sativa

* Correspondence and reprints

Tel. (34) 923219606; Fax. (34) 923219609; e-mail: ignac@gugu.usal.es 


\section{INTRODUCTION}

Forest biomass, forest ecology and the attendant uptake and nutrient management have been widely studied over the last few decades [10, 16, 17, 22, 30, 44].

The role of nutrients in forest ecology and productivity has recently received more attention [49, 50, 58], especially in relation to: (1) agricultural abandonment, which allows reforestation on much better soils than in the past, involving larger amounts of nutrients in the biogeochemical cycle of forests; (2) the increased nutrient input from dry atmospheric deposition and by rain, and their recycling within the biogeochemical cycle. There is now much available data on biomass and nutrient contents in various forest stands. However they mainly focus on highly productive or widely representative species, or are related to specific site conditions. Comparisons and extrapolations are also often limited by methodological differences.

Litter formation is a physiological process, affecting not only the soil but also the growth patterns and nutrition of plants. As other metabolic functions, it is likely to have become adapted to evolutionary forces, which generate a variety of strategies, that differ among plant species as well as among ecosystems [63].

Studies on foliar nutrient dynamics have been used to estimate the best time during the year for tissue sampling in nutritional studies [26], to determine retranslocation and internal cycling in forest ecosystems $[35,36,54]$, to estimate nutrient uptake [53] and to evaluate the adaptations of trees to nutrient stress [9].

Sweet chestnut (Castanea sativa Mill.) stands are very common around the western Mediterranean Basin. Formerly managed as coppices, these stands were regularly clear-cut every 15-25 years according to their productivity under various local conditions. However Castanea sativa coppice management is now more or less abandoned. Nevertheless, chestnut coppices cover fairly large areas in the Mediterranean mountains.

The role of these forest is not limited to production, but aesthetical and landscape safeguard aspects are also important. Traditional timber management of the chestnut grove is as follows: The chestnut trees are clear-cut every 20 to 25 years. Following this, the chestnuts grow spontaneously, and clearing of the sprouts is done after 5 to 10 years. Nevertheless the last century has been characterized by a progressive decrease in areas covered by chestnut forests. Over the last years, social interest in forest conservation has increased. Efforts have been made to save and improve existing chestnut stands; in this line, research has played a significant role in improving contributions to health aspects, nut quality and production, vegetative propagation, genetic improvement, economic and other cultivation aspects of chestnuts. It is thus necessary to conduct new research on the ecological role of chestnut species ( $C$. sativa, $C$. crenata, etc.) and the use of these forests as resources for sustainable development.

The aim of the present study was to estimate the aboveground stand biomass its nutrient contents litterfall and nutrient removal from trees to the soil and litter decomposition dynamics; to do so, allowed us to estimate organic matter dynamics as well as nutrient uptake from the soil of the chestnut forest ecosystem.

\section{MATERIALS AND METHODS}

\subsection{Study site}

The work was carried out in a Sweet chestnut forest in the "Sierra de Gata" mountains (province of Cáceres, Spain). This area forms part of the central range of the Iberian Peninsula, with maximum altitudes of about $1500 \mathrm{~m}$ a.s.l. The climate is mild Mediterranean, with rainy winters and warm summers. The mean temperature is around $15^{\circ} \mathrm{C}$ and precipitation reaches $1150 \mathrm{~mm}$.

A representative experimental chestnut forest plot was selected. This plot was selected at the "El Soto" zone, on the southern slope of the Sierra de Gata mountains, near the village of San Martín de Trevejo. The forest studied grows at $940 \mathrm{~m}$ a.s.1. on humic Cambisol soils. The bedrock is mainly weathered porphyric, calcoalkaline granite, with zones of colluvial granitic sands. The general slope is close to $45 \%$. The mean tree density is 3970 trees ha ${ }^{-1}$, with a mean D.B.H. (mean diameter at breast height, $1.3 \mathrm{~m}$ ) of $10 \mathrm{~cm}$ and a mean height of $13 \mathrm{~m}$, the mean basal area is $28.58 \mathrm{~m}^{2} \mathrm{ha}^{-1}$, and the L.A.I (leaf area index): $3.7 \mathrm{~m}^{2} \mathrm{~m}^{-2}$ (table I).

Table I. General characteristics of the studied chestnut stand.

\begin{tabular}{lc}
\hline Parameters (Chestnut stand) & San Martín de Trevejo site \\
\hline Altitude, ma.s.l. & 940 \\
Geology & Granite \\
Density (tree ha $\left.{ }^{-1}\right)$ & 3970 \\
D.B.H. $(\mathrm{cm})\left(\mathrm{Mean}^{1}\right.$ diameter & \\
at breast height, $1.3 \mathrm{~m})$ & 10.0 \\
Basal area $\left(\mathrm{m}^{2} \mathrm{ha}^{-1}\right)$ & 28.6 \\
Mean height $(\mathrm{m})$ & 13.0 \\
L.A.I. $\left(\mathrm{m}^{2} \mathrm{~m}^{-2}\right)($ leaf area index) & 3.7 \\
Long term mean P $(\mathrm{mm})($ annual rainfall) & 1152 \\
Mean annual temperature $\left({ }^{\circ} \mathrm{C}\right)$ & 14.2 \\
\hline
\end{tabular}




\subsection{Methods}

Four branches for 1-4 cm diameter and their leaves were sampled monthly during a vegetative cycle at three height levels (lower, medium and higher parts of the trees) within nine representative trees of different DBH classes of the stand for chemical analysis. The aboveground biomass and its nutrient content were estimated by harvesting 8 trees representative on different groups of $\mathrm{DBH}$ and height in the plot, during September 1992. The eight selected trees had a DBH from 4.0 to $17.2 \mathrm{~cm}$ and their heights ranged from 2.5 to $15.7 \mathrm{~m}$. The harvested trees were individually divided into sections according to their height (from 0 to $1.3 \mathrm{~m}, 1.3-3.0 \mathrm{~m}, 3-5 \mathrm{~m}, 5-7 \mathrm{~m}, 7-9 \mathrm{~m}$, 9-11 m, and so on), depending of height of each tree, and from each section different parts of the tree (trunks, branches and leaves) were wet weighed in the field.

Three groups of ten boxes each with a surface of $0.24 \mathrm{~m}^{2}, 30 \mathrm{~cm}$ high were placed systematically following transects based on the topography of the soil in the experimental plot to collect litter fall. This litter was collected at approximately monthly intervals, (from once a month to once every 2 weeks during the period of most rapid leaf fall) and separated into individual components (leaves, branches, buds, flowers, nuts, and others), weighing each one after drying at $80{ }^{\circ} \mathrm{C}$. Following this, the samples were ground for chemical analysis. Fiftyfour nylon litter-bags ( $1 \mathrm{~mm}$ mesh) were placed on the forest soil, in three groups at different places on the experimental chestnut plot. Each bag held $10.0 \mathrm{~g}$ of leaves issued from its site canopy, previously dried at room temperature and the remaining humidity determined by drying at $80{ }^{\circ} \mathrm{C}$ until constant weight. Three bags were taken out every two months, and after drying them, these samples were weighed and analyzed. Necromass of the forest floor was also quantified by collecting 15 replicates of $0.25 \mathrm{~m}^{2}$ sections of the superficial holorganic soil horizon, no including humus. Likewise, to determine the constants it was necessary to know leaf and litter production, which was achieved by placing the three groups of ten boxes of $0.24 \mathrm{~m}^{2}$ surface-area on plot.

\subsection{Chemical analysis and nutrient determination}

Representative biomass and litter samples were ground, and then subjected to chemical analysis. After digestion of the plant material, $\mathrm{Ca}, \mathrm{Mg}$ and $\mathrm{K}$ were determined using atomic absorption spectrophotometry or flame photometry. Phosphorus was determined colorimetrically using metavanadate [15] and nitrogen by the Kjeldahl method or directly with a macro-N Heraeus device. The results, expressed as percentage of the plant tissue, were correlated with the biomass or litter-fall val- ues to determine the amount of nutrients in the biomass or litter on a surface area basis.

\subsection{Statistical analysis}

Statistical analysis was performed by a one-way analysis of variance (ANOVA), comparing the amounts of litter fall over time (three different years). Regression equations were developed to estimate the total of tree component biomass.

For the evaluation of litter dynamics, we used the $K$ coefficient [27], which relates the humus and the aboveground litter.

The data were subjected to a one-way statistical analysis of variance algorithm (ANOVA). The regression curves were also established according to the best $r^{2}$. Linear regressions were performed with the natural logarithm of the mean dry matter remaining at each time to calculate $K$, a constant of the overall fractional loss rate for the study period, following the formula:

$$
\ln (X t / X 0)=K t
$$

where $X t$ and $X 0$ are the mass remaining at time $t$ and time zero, respectively [45]. Both masses remaining on the soil were calculated immediately before the annual litterfall peak.

\section{RESULTS}

\subsection{Aboveground biomass estimation and nutrient storage}

In order to obtain the most accurate biomass estimations the most common methods proposed in the literature were tested [59]. Different independent variables such as the DBH, basal area, height $(H)$, circumference and several combinations of these $\left(\mathrm{DBH}^{2}, \mathrm{DBH}^{2} H\right.$, $H / \mathrm{DBH}, \mathrm{DBH} / H)$ were also tested.

The results showed that the model best fitted (based on the residual analyses) was obtained applying the allometric equations:

$$
\begin{gathered}
Y=a X^{b} \\
Y=a X^{b} H^{c}
\end{gathered}
$$

where $Y$ is the total aboveground biomass (dry weight), $X$ is the tree's DBH and $H$ its height.

The regression equations for estimating aboveground biomass by tree components are shown in table II. For each DBH category the biomass of the tree type was calculated. This value was then multiplied by the number of 
Table II. DBH-biomass relation in the different compartments of the trees.

\begin{tabular}{llcc}
\hline & \multicolumn{1}{c}{ Equations } & $n$ & $r^{2}$ \\
\hline Total aboveground & & & \\
biomass: & $y=0.066 \mathrm{DBH}^{2.647}$ & 36 & 0.998 \\
Trunk biomass: & $y=0.079 \mathrm{DBH}^{2.541}$ & 36 & 0.996 \\
Branches biomass & $y=0.000467 \mathrm{DBH}^{3.675}$ & 20 & 0.982 \\
Leaf biomass & $y=0.0000544 \mathrm{DBH}^{3.943}$ & 36 & 0.860 \\
\hline
\end{tabular}

shoots in that category in the stand so as to obtain the total biomass for the stand [32].

The highest concentration of elements was found in the foliage (table III) and decreasing in the following order: foliage $>$ branches $>$ trunk. The elements with the highest concentrations in the leaves are $\mathrm{N}, \mathrm{Mg}, \mathrm{P}$ and $\mathrm{K}$. These concentrations showed differences throughout the phenological cycle.

\subsection{Seasonal variation in leaf nutrient content}

Table IV shows the monthly evolution of the dry weight and the mineral element concentrations in leaves during a vegetative cycle. Leaf samples from chestnut stand were collected at three height levels of the tree canopy.

Different patterns were found for the nutrients studied. Concentrations decreased in the case of N, P and K; the $\mathrm{Mg}$ showed an unvarying pattern. $\mathrm{Ca}$ increased in concentration during the vegetative cycle.

\subsection{Litterfall and its nutrient content}

Annual litter fall production and potential nutrient return are indicated in table $V$. As in the case of most forest ecosystems, the leaves comprised the most important fraction (3429 $\mathrm{kg} \mathrm{ha}^{-1} \mathrm{y}^{-1}$ ), representing $69.8 \%$ of the total contribution. Branch fall can be said to be intimately linked to that of leaves, although its contribution was smaller and only represented $14.8 \%$ of the total litterfall. Flowers and fruits represented $8.8 \%$ and $5.1 \%$ respectively of the annual total litterfall added to the humus, with an amount of flowers of $432 \mathrm{~kg} \mathrm{ha}^{-1} \mathrm{y}^{-1}$ and an amount of fruits of $250 \mathrm{~kg} \mathrm{ha}^{-1} \mathrm{y}^{-1}$.

The soil of chestnut stand received a mean potential contribution of 53.9, 23.7, 13.0, 7.8 and $18.7 \mathrm{~kg} \mathrm{ha}^{-1} \mathrm{y}^{-1}$ of $\mathrm{N}, \mathrm{Ca}, \mathrm{Mg}, \mathrm{P}$ and $\mathrm{K}$ respectively (table $\mathrm{V}$ ). The leaf litter was the main vector of the potential return of all bioelements to the holorganic horizon, followed in order of importance by flowers for $\mathrm{N}, \mathrm{P}$ and $\mathrm{Mg}$; branches for $\mathrm{Ca}$, fruits for $\mathrm{K}$.

The rotation coefficient - nutrients in leaf litterfall $\times$ 100 /nutrients in biomass - indicated interesting values for the chestnut stand studied, $\mathrm{Ca}$ was recycled more slowly than the other nutrients, and $\mathrm{N}$ was recycled faster, with the values: $\mathrm{N}=70.8, \mathrm{Ca}=15.8, \mathrm{Mg}=45.6$, $\mathrm{P}=23.2, \mathrm{~K}=39.8$.

Table III. Aboveground biomass $\left(\mathrm{kg} \mathrm{ha}^{-1}\right)$ and concentration of bioelements in the different compartment of the trees.

\begin{tabular}{|c|c|c|c|c|c|c|c|c|c|c|c|}
\hline & $\mathrm{kg} \mathrm{ha}^{-1}$ & $\% \mathrm{~N}$ & $\mathrm{~kg} \mathrm{ha}^{-1}$ & $\% \mathrm{Ca}$ & $\mathrm{kg} \mathrm{ha}^{-1}$ & $\% \mathrm{Mg}$ & $\mathrm{kg} \mathrm{ha}^{-1}$ & $\% \mathrm{P}$ & $\mathrm{kg} \mathrm{ha}^{-1}$ & $\% \mathrm{~K}$ & $\mathrm{~kg} \mathrm{ha}^{-1}$ \\
\hline Trunk & 104702 & $0.056 \pm 0.020$ & 58.6 & $0.112 \pm 0.006$ & 117.2 & $0.023 \pm 0.001$ & 24.1 & $0.028 \pm 0.004$ & 29.3 & $0.037 \pm 0.006$ & 38.7 \\
\hline Branches & 11807 & $0.601 \pm 0.024$ & 71.0 & $0.350 \pm 0.018$ & 41.3 & $0.141 \pm 0.008$ & 16.6 & $0.078 \pm 0.007$ & 9.2 & $0.326 \pm 0.035$ & 38.5 \\
\hline Leaves & 2938 & $1.530 \pm 0.121$ & 45.0 & $0.326 \pm 0.011$ & 9.6 & $0.276 \pm 0.006$ & 8.1 & $0.249 \pm 0.011$ & 7.3 & $0.920 \pm 0.047$ & 27.0 \\
\hline Total & 119447 & & 174.6 & & 168.1 & & 48.8 & & 45.8 & & 104.2 \\
\hline
\end{tabular}

Table IV. Variation of nutrients (\%) of the leaves during a vegetative cycle.

\begin{tabular}{|c|c|c|c|c|c|c|}
\hline Date & a leaf dry weight (g) & $\mathrm{N}$ & $\mathrm{P}$ & $\mathrm{K}$ & $\mathrm{Ca}$ & $\mathrm{Mg}$ \\
\hline 28.04 & $0.13 \pm 0.03$ & $2.85 \pm 0.33$ & $0.28 \pm 0.02$ & $1.21 \pm 0.09$ & $0.19 \pm 0.02$ & $0.27 \pm 0.02$ \\
\hline 25.05 & $0.13 \pm 0.03$ & $2.65 \pm 0.30$ & $0.31 \pm 0.02$ & $1.24 \pm 0.09$ & $0.28 \pm 0.03$ & $0.30 \pm 0.03$ \\
\hline 28.06 & $0.23 \pm 0.04$ & $2.20 \pm 0.24$ & $0.21 \pm 0.01$ & $1.10 \pm 0.08$ & $0.31 \pm 0.04$ & $0.24 \pm 0.02$ \\
\hline 27.07 & $0.34 \pm 0.06$ & $2.01 \pm 0.19$ & $0.24 \pm 0.02$ & $1.08 \pm 0.08$ & $0.25 \pm 0.03$ & $0.27 \pm 0.03$ \\
\hline 25.08 & $0.40 \pm 0.07$ & $1.96 \pm 0.16$ & $0.24 \pm 0.02$ & $1.00 \pm 0.08$ & $0.33 \pm 0.05$ & $0.29 \pm 0.03$ \\
\hline 28.09 & $0.40 \pm 0.07$ & $1.59 \pm 0.12$ & $0.26 \pm 0.03$ & $1.01 \pm 0.08$ & $0.34 \pm 0.05$ & $0.27 \pm 0.02$ \\
\hline 02.11 & $0.43 \pm 0.08$ & $0.82 \pm 0.07$ & $0.24 \pm 0.02$ & $0.58 \pm 0.04$ & $0.40 \pm 0.06$ & $0.27 \pm 0.03$ \\
\hline
\end{tabular}


Table V. Average annual litter production and bioelement amounts of litterfall components $\left(\mathrm{kg} \mathrm{ha}^{-1} \mathrm{y}^{-1}\right)$.

\begin{tabular}{|c|c|c|c|c|c|c|c|}
\hline & \multicolumn{2}{|c|}{ Litter production } & \multicolumn{5}{|c|}{$\mathrm{kg} \mathrm{ha}^{-1} \mathrm{y}^{-1}$} \\
\hline & $\mathrm{kg} \mathrm{ha}^{-1} \mathrm{y}^{-1}$ & $\%$ & $\mathrm{~N}$ & $\mathrm{Ca}$ & $\mathrm{Mg}$ & $\mathrm{P}$ & K \\
\hline Leaves & 3429 & 69.8 & 41.5 & 18.5 & 11.0 & 6.8 & 15.4 \\
\hline Branches & 728 & 14.8 & 3.2 & 3.0 & 0.5 & 0.1 & 0.6 \\
\hline Flowers & 432 & 8.8 & 5.1 & 0.9 & 0.8 & 0.5 & 0.2 \\
\hline Fruits & 250 & 5.1 & 2.6 & 0.8 & 0.5 & 0.3 & 2.1 \\
\hline Others & 73 & 1.5 & 1.5 & 0.5 & 0.2 & 0.1 & 0.4 \\
\hline Total & 4912 & 100.0 & 53.9 & 23.7 & 13.0 & 7.8 & 18.7 \\
\hline
\end{tabular}

Table VI. Litter decay indices $(K$ and $K o$ ) for leaf litter and for total litter.

\begin{tabular}{lccccccc}
\hline Litter fraction & $A$ & $F$ & $A+F$ & $K$ & $K$ o & $P$ & $K$ d \\
\hline Leaves & 3429 & 322 & 7751 & 0.44 & 0.79 & 1509 & 0.56 \\
Total litter & 4912 & 7693 & 12605 & 0.39 & 0.64 & 1916 & 0.61
\end{tabular}

$A$, annual production; $F$, litter or leaves accumulated in the soil; $K$, Jenny's index; $K$, Olson's index; $P$, annual loss of produced fallen litter or leaves; $K$ d, coefficient of accumulation of fallen litter or leaves.

The constants and parameters are according to the equations: $K=A /(A+F), P=A K, K \mathrm{o}=A / F, K \mathrm{~d}=(A-P) / A$.

Table VII. Organic matter dynamics (\%) and average concentration of bioelements $\left(\mathrm{mg} \mathrm{g}^{-1}\right)$ during the decomposition experiment.

\begin{tabular}{lcccccc}
\hline Days & O.M. & $\mathrm{N}$ & $\mathrm{Ca}$ & $\mathrm{Mg}$ & $\mathrm{P}$ & $\mathrm{K}$ \\
\hline 0 & 1.00 & 10.8 & 5.6 & 1.7 & 0.9 & 1.5 \\
60 & $0.98 \pm 0.01$ & $10.1 \pm 0.2$ & $5.2 \pm 0.6$ & $1.6 \pm 0.2$ & $0.9 \pm 0.2$ & $1.3 \pm 0.2$ \\
124 & $0.96 \pm 0.01$ & $9.8 \pm 0.3$ & $6.3 \pm 0.4$ & $1.7 \pm 0.1$ & $0.8 \pm 0.1$ & $1.2 \pm 0.1$ \\
180 & $0.92 \pm 0.01$ & $10.4 \pm 0.3$ & $6.1 \pm 0.3$ & $2.0 \pm 0.3$ & $1.0 \pm 0.2$ & $1.3 \pm 0.2$ \\
247 & $0.82 \pm 0.01$ & $10.3 \pm 0.3$ & $6.5 \pm 0.4$ & $2.2 \pm 0.2$ & $0.8 \pm 0.1$ & $1.4 \pm 0.1$ \\
310 & $0.80 \pm 0.01$ & $11.0 \pm 0.4$ & $6.7 \pm 0.3$ & $2.4 \pm 0.3$ & $0.8 \pm 0.1$ & $0.9 \pm 0.1$ \\
366 & $0.78 \pm 0.02$ & $12.1 \pm 0.4$ & $6.9 \pm 0.5$ & $1.9 \pm 0.4$ & $0.7 \pm 0.2$ & $1.0 \pm 0.1$ \\
430 & $0.70 \pm 0.03$ & $12.9 \pm 0.5$ & $6.7 \pm 0.4$ & $1.8 \pm 0.2$ & $1.1 \pm 0.1$ & $0.8 \pm 0.1$ \\
508 & $0.69 \pm 0.02$ & $14.6 \pm 0.5$ & $5.8 \pm 0.6$ & $2.0 \pm 0.3$ & $1.2 \pm 0.1$ & $1.3 \pm 0.2$ \\
551 & $0.66 \pm 0.02$ & $15.6 \pm 0.6$ & $5.3 \pm 0.5$ & $1.9 \pm 0.2$ & $1.1 \pm 0.1$ & $1.0 \pm 0.2$ \\
615 & $0.54 \pm 0.04$ & $17.9 \pm 0.6$ & $6.7 \pm 0.6$ & $1.8 \pm 0.1$ & $1.3 \pm 0.2$ & $1.4 \pm 0.2$ \\
677 & $0.52 \pm 0.04$ & $17.4 \pm 0.5$ & $6.4 \pm 0.5$ & $1.8 \pm 0.1$ & $1.4 \pm 0.2$ & $0.9 \pm 0.1$ \\
740 & $0.53 \pm 0.04$ & $16.5 \pm 0.4$ & $6.0 \pm 0.3$ & $1.9 \pm 0.1$ & $1.2 \pm 0.1$ & $0.9 \pm 0.1$ \\
\hline
\end{tabular}

\subsection{Litter decomposition}

Jenny's and Olson's decomposition constants were determined for leaves only and for total litter (table VI). Considering both total litter and leaves separately, higher $K$ and $K$ o decomposition indices were estimated for leaves alone than for total litter.

At the end of decomposition period the loss of dry matter was $47 \%$ (table VII). Nutrient concentrations, expressed as $\mathrm{mg} \mathrm{g}^{-1}$ are shown in (table VII).

\section{DISCUSSION}

\subsection{Aboveground biomass estimation and nutrient storage}

Although equation (1) gives quite similar results, the estimates are slightly improved for some of the fraction when equation (2) is used. However, the inclusion of height involves an additional practical problem in data collection even though it does reflect characteristics affecting the biomass [13]. 
Equation (1) can be considered optimal when it includes the DBH as the only explicative variable in all cases. The DBH is the parameter most commonly used because of the ease and precision with which it can be calculated and because it is related to the volume of the wood and with functional processes such as transport and the age of the tree $[19,59]$.

Extrapolation of these findings should be done with caution since the factors affecting productivity vary considerably in any given forest because they are in turn affected by orientation, soil depth, fertility, type of substrate, microclimatic characteristics, density, age, management, etc. [2, 11, 32, 52]. However, extrapolation to other areas is debatable since it involves a loss of precision in the estimation $[11,23,43]$.

The trunk accumulated the higher amount of all of these bioelements on a weight basis, owing to its high biomass (about $88 \%$ overall). The amount of nutrients accumulated in the leaves, on a weight basis, was quantitatively lower because foliage biomass represented only about $2.5 \%$ of the total biomass. However, despite this low percentage, the amount of bioelements accumulated in leaves is of great qualitative importance since these organs are subject to internal annual cycles (deciduous species) and eventually a proportion of them returns to the soil in the leaf litter. The amount of nutrients stored in the leaves depends, above all, on the leaf biomass of the forest. Accordingly, the extent of this storage varies considerably at each site, with a mean storage of about $25 \%$ of $\mathrm{N}$ and $15 \%$ of the $\mathrm{P}$ and $\mathrm{Mg}$ of the total mineralomass. These nutrient distributions have practical implications, since the high removal of nutrients from the sites with full-tree harvesting systems, as compared to the traditional method of harvesting of trunks, results in a lower loss of nutrients from the site $[12,28,60]$.

The order of accumulation of elements studied in these forests is as follows: $\mathrm{N}>\mathrm{Ca}>\mathrm{K}>\mathrm{Mg}>\mathrm{P}$.

Nevertheless, the distributions of nutrients within the trees are closely associated with the biological activity of tree compartments, and with the physiological activity of leaves. The total weight of bioelements in both trees and in the forest stand can be calculated by multiplying the bioelement concentration by the dry weight of either the tree or each component biomass of the stand [28, 66]. Castanea sativa exhibited differential characters in the storage and concentrations of nutrients in the different parts of the tree in relation to others hardwood species $[25,31,60]$.

\subsection{Seasonal variation in leaf nutrient content}

Dry weight increased significantly throughout the growing season. Seasonal increases in mass of current foliage have been reported for [67] and [24].
Different patterns were found for the nutrients studied. Concentrations decreased in the case of N, P and $\mathrm{K}$ at the end of the vegetative cycle; the $\mathrm{Mg}$ showed an unvarying pattern, and $\mathrm{Ca}$ increased in concentration during the vegetative cycle.

The vegetative cycle of deciduous forest leaves is subject to three stages of development: rapid growth, maturation and senescence. During the first period, the relative concentrations of mobile biological macronutrients, $\mathrm{N}, \mathrm{P}, \mathrm{K}$ were the highest, thereafter decreasing to the end of vegetative cycle on the plot studied. The decrease would be due to the fact that the increase in dry weight of the recently matured leaves was faster than the translocation of nutrients into the leaves [24]. These changes have been attributed to resorption of nutrients from the foliage into perennial tissues $[9,47,53,65]$. During the spring, growth is accompanied by an intense mitotic activity due to cellular growth and a strong demand for nutrients, in particular N [53]. Thereafter, the contents of this element decrease throughout the vegetative cycle and above all during the period of senescence (autumn). It is therefore evident that retranslocation to perennial tissues occurs before total abscission. The low variation in the concentration of these organs masks more important absolute variations when considering the relative mass of leaves. The transfer of $\mathrm{N}$ to the perennial parts of the tree may represent $30-50 \%$ of the amount required for the biomass production of the following cycle [24].

The concentration of $\mathrm{Ca}$, considered to be an immobile element, increases until leaf abscission, resulting from accumulation in the cell walls and perhaps from lignification of the tissues. Similar pattern was reported in $[3,10]$.

The concentration of $\mathrm{Mg}$ remained constant during the vegetative cycle at all the sites considered. The fact that the amounts of retranslocated elements of the leaves are more related to their individual concentrations in plant organs than to their availability in soil highlights the indirect nature of the effect of the substrate in this context.

\subsection{Litterfall and nutrient return to the soil}

Important annual variations were estimated in the fall or organs. Maximum production peaks occurred in autumn, although there were small peaks in spring and the start of summer, mainly due to the shedding of flowers, and leaves owing to adverse climatological conditions (late freezes). Accordingly, the annual fall cycle (deciduous species) is mainly determined by the cycle of leaf and branch abscission.

In the studied stand, the length of the biological activity period is mainly affected by two factors: low winter temperatures and summer drought. In many cases, the 
contribution of ground vegetation was not considered because of its relative unimportance to total amounts of annual litterfall.

The values of total litterfall obtained were greater than the $3.6 \mathrm{mg} \mathrm{ha}^{-1} \mathrm{y}^{-1}$ estimated by [1], $3.9 \mathrm{mg} \mathrm{ha}^{-1} \mathrm{y}^{-1}$ reported by [48] in chestnut coppices used for fruit collection (or lesser density) and the 1.7 and $2.6 \mathrm{mg} \mathrm{ha}^{-1} \mathrm{y}^{-1}$ recorded by [33] in chestnut coppices cleared every seven years. Likewise, they are similar to the $5.2 \mathrm{mg} \mathrm{ha}^{-1} \mathrm{y}^{-1}$ given by [46] for deciduous forests, although lower than the $6.3 \mathrm{mg} \mathrm{ha}^{-1} \mathrm{y}^{-1}$ reported by [54] for a chestnut stand in the Sierra de Béjar.

The annual cycle of leaf fall in Castanea sativa is practically limited to October and November, later contributions being due to the fact that the leaves still on the lower branches of the trees show a marked marcescence, and persist in their location over a large part of the winter, these contributions are also due to late frosts.

In general, it may be assumed that in the study area the effect of wind did not markedly affect the seasonality of the contribution of plant debris to the soil (there were no significant correlations between wind speed and the fall of leaves, branches, or total aboveground litter production [20].

In most forest ecosystems the production of organs related to reproduction usually varies considerably from one year to another, and this variation also involves the other organs of the tree $[4,14,21,62]$. The shedding of flowers is subject to their annual cycle of fall, and practically restricted to July to September in the chestnut stand.

The fraction corresponding to the fruits displays a maximum period of fall corresponding to NovemberDecember, with a marked seasonality. The mean estimated annual production of these organs is much lower than those obtained for two chestnut orchards in western Spain [20] and northern Portugal [48].

The variations in the return of bioelements to the soil through litter follow a similar evolution to shedding, since this variation was more important than that observed in the composition of the plant organs. Nitrogen was the major nutrient as regards quantitative importance, the leaves being the organs which showed the highest levels of this element (table IV). [33] found amounts of $\mathrm{N}$ similar to those in four Sicilian chestnut coppices.

The Ca contents were among the lowest found in the literature, both for leaves and for the other fractions [33, $54,55,56]$, although it should be remembered that those coppices were located on very different types of soil. It is necessary to take into account the "dilution effect" (an increase in biomass while maintaining the same amount of bioelements) that may occur due to the different amounts of litter; that is, if it assumed that the same amount of $\mathrm{Ca}$ is absorbed on soils with the same amount of assimilable $\mathrm{Ca}$, the concentration in the litter would be lower in forests with a higher production $[20,38]$.

The Mg content of all the organs was within the limits reported in the literature [29], the highest values corresponding to the leaves (table $V$ ). It would appear that the uptake of $\mathrm{Mg}$ into leaves could be favored by the scarcity of $\mathrm{Ca}$ (nutritional imbalance).

The chestnut stand studied had the highest $\mathrm{P}$ amounts in the leaves. These amounts circulating in the chestnut ecosystem through the leaves are in an intermediate position with respect to the data found in the literature referring to Castanea sativa [48].

[20] pointed out that the amount of available soil $\mathrm{P}$ in the stand studied appeared to be sufficient to satisfy plant requirement as long as there were no adverse circumstances (prolonged summer drought).

The highest $\mathrm{K}$ concentration was linked to a lower concentration in $\mathrm{Ca}$ due to the known antagonism between these two elements; accordingly, the highest concentrations were found in the shortest-lived organs. By contrast, [48] obtained higher values for $\mathrm{K}$ than $\mathrm{Ca}$, undoubtedly due to the greater abundance of shorter-lived organs, in which $\mathrm{K}$ acquires considerable importance.

It appears that nutrient management is related to their availability in the soil. Nutrients present in lower amounts are recycled through the plant-soil system in much higher proportions than other nutrients available in higher quantities in these soils [34].

\subsection{Litter decomposition}

Organic matter loss of leaves when confined to litterbags at the end of the first year was lower than those obtained under natural conditions (22\% in the litterbags, table VII, $K=0.44, K o=0.39$ under natural conditions, table VI).

The $F$ values may be underestimated, since it is often difficult to distinguish decomposing leaves from other plant remains, especially when small amounts of old litter $(F)$ are involved. $F$ had fairly low values that cannot be entirely explained by the presence of twig and barks rich in lignin substances [39] and low in N [3].

The leaf litter decomposition constants are higher than the total litter decomposition constants, because to the total litter includes more wood lignin [39, 40, 42] than the leaves or needles alone.

A halt in decay occurs nearly during the dry summer periods taking into account that the litter dries before the soil, and also becomes wet before the soil (because of the dew effect), with mineralization continuing when 
humidity is high despite the lower temperatures; in this case, a temperature increase of a few degrees in the wet period has significant effects [61]. The effect of the dry period on leaf decay has been addressed in depth by [37]. As a result, in these forest ecosystems, leaf-litter decay is linked above all to humidity itself [8], mineralization slowing down when the leaf litter is dry (the soil may continue to be moist to a depth of more than $40 \mathrm{~cm}$ ). [64] stressed, however, that physical and physicochemical processes of decay occur in summer (losses of dry matter due to animals, water or winds, could be limited).

Table VII shows changes in remaining organic matter (O.M.) and bioelements in decomposing chestnut leaves.

A relative increase in the $\mathrm{N}$ concentration was observed, this increase is not reflected as an absolute increase; the enrichment in $\mathrm{N}$ of the leaf organs after the first months of the experimental period has already been discussed by several authors, such as [6], and even absolute increases have been found [7]. About 20\% of the initial $\mathrm{N}$ was lost (table VII) during the two years of decay studied.

Certain relationship was reported between the decomposition process and the accumulation of nitrogen [6]. Low $\mathrm{N}$ concentrations in the soil give rise to larger increases in $\mathrm{N}$ during the initial stages of decomposition. It is possible, however, that the abundance of polyphenolic substances, typical of conifer residues [41, 57], could exert an inhibitory action on fungal growth, leading to slow hyphal growth in decomposing leaves, and hence low immobilization by the fungal biomass.

The concentration of $\mathrm{Ca}$ was also found to increase relatively throughout the decay period studied; since $\mathrm{Ca}$ is a scant element in acid soils, it is subject to strong biological immobilization [18]. Mg followed a very irregular trend, although it was observed that after the summer (dry period) an increase, both relative and absolute, in $\mathrm{Mg}$ contents occurred; this can be attributed to a washing of the tree canopy, that would have enriched the remaining leaves. Certain authors, such as [51], have suggested that $\mathrm{Mg}$ is a readily leachable bioelement, and that it seems to reflect a balance between losses (due to washing) and contributions (due to throughfall and atmospheric dusts). The relative content of $\mathrm{P}$ tended to remain constant, even to increase, owing to exogenous contributions by throughfall. The scarceness of this bioelement in the aboveground biomass must be a factor that governs its retention by microbial activity. In free form, $\mathrm{K}$ is a highly abundant element in plant tissues, and hence it is easily leachable; the evolution of this bioelement during the decay period studied showed strong fluctuations. These accounted for the increases in $\mathrm{K}$ that decaying leaves must undergo due to leaching from the forest canopy and to a certain degree of heterotrophic immobilization [5].
Trends in the behavior of the other bioelements are hindered by their low concentration in chestnut leaves.

\section{CONCLUSIONS}

The results show that the model best fitted (based on residual analyses) was that obtained applying the allometric equation $Y=a X^{b}$. The trunk accumulated the highest amount of all the nutrients considered on a weight basis owing to high biomass. The amount of nutrients accumulated in the leaves was quantitatively lower because foliage biomass represented only about $2.5 \%$ of the total aboveground biomass.

Nutrients showed the highest concentrations in the leaves (except $\mathrm{Ca}$ ). Their concentrations generally decreased in the following order: foliage > branches > trunk.

The monthly evolution for the dry weight and mineral element concentrations in leaves during a vegetative cycle showed that concentrations decreased in the case of $\mathrm{N}, \mathrm{P}$, and $\mathrm{K} ; \mathrm{Mg}$ showed an unvarying pattern, and $\mathrm{Ca}$ increased in concentration during the vegetative cycle.

The leaves comprised the most important fraction of the total litterfall, representing $69.8 \%$. Branch fall represented $14 \%$ of the total litterfall. Flowers and fruits represented $8.8 \%$ and $5.1 \%$ respectively of the annual total litterfall added to the humus.

Organic matter loss of leaves confined to litterbags at the end of the first year was lower than Jenny's and Olson's decomposition constants obtained under natural conditions ( $22 \%$ in the litterbags and $K=0.44, K o=0.39$ under natural conditions). Considering both total litter and leaves separately, higher $K$ and $K$ o decomposition constants were estimated for leaves alone than for total litter. At the end of decomposition period the loss of dry matter was $47 \%$.

Acknowledgements: This work was made possible through the financial support of the STEP/D.G. XII (EC) program. Technical assistance was obtained from $\mathrm{C}$. Relaño.

\section{REFERENCES}

[1] Anderson J.M., Stand structure and litter fall of a coppiced beech Fagus sylvatica and sweet chestnut Castanea sati$v a$ woodland, Oikos 24 (1973) 128-135.

[2] Baskerville G.L., Use of logarithmic Regression in the Estimation of Plant Biomass, Can. J. For. 2 (1972) 49-53.

[3] Berg B., Dynamics of nitrogen $\left({ }^{15} \mathrm{~N}\right)$ in decomposing Scots pine (Pinus sylvestris) needle litter: Long-term decomposition in a Scots pine forest. VI, Canadian J. Bot. 66 (1988) 1539-1546. 
[4] Berg B., Albrecktson A., Berg M. P., Cortina J., Johansson M. B., Gallardo A., Madeira M., Pausas J., Kratz W., Vallejo R., McClaugherty Ch., Amounts of litter fall in some pine forests in European transect, in particular Scots pine, Ann. For. Sci. 56 (1999) 625-640.

[5] Berg B., Staaf H., Decomposition rate and chemical changes of scots pine needle litter. II: Influence of chemical composition. Structure and function of Northern coniferous forests. An ecosystem study, Persson T. (Ed.), Ecol. Bull. (Stockholm) 32 (1980) 373-390.

[6] Berg B., Staaf H., Leaching accumulation and release of nitrogen in decomposing forest litter, in: Terrestrial nitrogen cycles, F.E. Clark \& T. Rosswall, Ecol. Bull. 33 (1981) 163-178.

[7] Berg B., Theander O., Dynamics of some nitrogen fraction in decomposing scots pine needle litter, Pedobiology 27 (1984) 261-267.

[8] Beyer L., Irmler V., The structure of humus and dynamic of litter decomposition on a Luvisol and a Podsol under Forests, Pedobiology 35 (1991) 368-380.

[9] Boerner R.E.J., Foliar nutrient dynamics, growth and nutrient use efficiency of Hammamelis virginiana in three forest microsites, Can. J. Bot. 63 (1985) 1476-1481.

[10] Bray J.R., Gorham E., Litter production in forests of the world, Adv. Evol. Res. 2 (1964) 101-157.

[11] Brown S., Gillespie A.J.R., Lugo A.E., Biomass estimation methods for tropical forest with applications to forest inventory data, For. Sci. 35 (1989) 881-902.

[12] Cabanettes A., Rapp M., Biomasse, minéralomasse et productivité d'un ecosystème à pins pignons (Pinus pinea $\mathrm{L}$.) du littoral méditerranéen. I, Biomasse. Oecol. Plant. 13 (1978) 271-286.

[13] Campbell J.S., Lieffers V.J., Pielou E.C., Regression equations for estimating single tree biomass of trembling aspens: assessing their applicability to more than one population, For. Ecol. Manag. 11 (1985) 283-295.

[14)] Canellas I., San Miguel A., Litterfall and nutrient turnover in Kermes oak (Quercus coccifera L.) shrublands in Valencia (eastern Spain), Ann. Sci. For. 55 (1998) 589-598.

[15] Chapman H.D., Pratt P.F., Métodos de análisis para suelos, plantas y aguas, Trillas, México, 1979, 195 p.

[16] Cole D.W., Rapp M., Elemental cycling in forest ecosystems, in: Reichle D.E. (Ed.), Dynamic properties of forest ecosystems, IPB 23, Cambridge Univ. Press, Cambridge, 1980, pp. 341-409.

[17] Douglas A.F., McNaughton S.J., Aboveground biomass estimation with the canopy intercept method: a plant growth form caveat, Oikos 57 (1990) 57-60.

[18] Duchaufour P.H., Edafología. I. Edafogénesis y clasificación, Masson, Barcelona, Spain, 1984, 493 p.

[19] Freedman B., Duinker P.N., Morash R., Biomass and nutrient in nova forests and implications of intensive harvesting for future site productivity, For. Ecol. Manag. 15 (1986) 103-127.

[20] Gallardo J.F., Martín A., Santa Regina I., Nutrient cycling in deciduous forest ecosystems of the Sierra de Gata mountains: aboveground litter production and potential nutrient return, Ann. Sci. For. 55 (1998) 749-769.

[21] Gallardo J.F., Martín A., Santa Regina I., Nutrient cycling in deciduous forest ecosystems of the Sierra de Gata mountains: nutrient supplies to the soil through both litter and throughall, Ann. Sci. For. 55 (1998) 771-784.

[22] Grier Ch. C., Elliot K.J., McCullough D.G., Biomass distribution and productivity of Pinus edulis. Juniperus monosperma woodlands of north-Central Arizona, For. Ecol. Manag. 50 (1992) 331-350.

[23] Harding R.B., Grial D.F., Site quality influences on biomass estimates for white spruce plantations, For. Sci. 32 (1986) 443-446.

[24] Helmisaari H.S., Temporal variation in nutrient concentrations of Pinus sylvestris needles, Scand. J. For. Res. 5 (1990) 177-193.

[25] Helmisaari H.S., Nutrient retranslocation within foliage of Pinus sylvestris, Tree Physiol. 10 (1992) 45-58.

[26] Hoyle M.C., Variation in foliage composition and diameter growth of yellow birch with season, soil and tree size, Soil Sci. Soc. Am. Proc. 29 (1965) 475-480.

[27] Jenny H., Gessel S.P., Bingham F.T., Comparative study of decomposition rates of organic matter in temperate and tropical regions, Soil Sci. 68 (1949) 419-432.

[28] Jokela E.J., Shannom C.A., Withe E.H., Biomass and nutrient equations for nature Betula papyrifera, Can J. For. Res. 11 (1981) 298-304.

[29] Khanna P.K., Ulrich B., Ecochemistry of temperate diciduous forests, in: Röhrig E. \& Ulrich B. (Eds.) Ecosystems of the world. 7. Temperate dedicuous forests, Elsevier, Amsterdam, 1991, pp. 121-163.

[30] Kira T., Shidei T., Primary production and turnover of organic matter in different forest ecosystems of the Western Pacific, Jap. J. Ecol. 17 (1967) 70-81.

[31] Lemoine B., Ranger J., Gelpe J., Distribution qualitative et quantitative des éléments nutritifs dans un jeune peuplement de Pin maritime (Pinus pinaster Ait), Ann. Sci. For. 45 (1988) 95-116.

[32] Leonardi S., Rapp M., Denes A., Organic matter distribution and fluxes within a holm oak (Quercus ilex L.) stand in the Etna Volcano, Vegetatio 99-100 (1992) 219-224.

[33] Leonardi S., Rapp M., lzzo R., Failla M., Guarniccia D., De Santis C., Chestnut ecosystem function: nutrient cycling processes within several stands in relation to age and altitude on the Etna Volcano, in: Romane (Ed.) Biological Criteria for Sustainable Development in Natural Degenerate Forests of Mediterranean Europe, Montpellier, 1994, pp. 45-61.

[34] Leonardi S., Santa Regina I., Rapp M., Gallego H.A., Rico M., Biomass. Litterfall and nutrient content in Castanea sativa copicce stands of southern Europe, Ann. Sci. For. 53 (1996) 1071-1081.

[35] Lim M.T., Cousens J.E., The internal transfer of nutrients in a Scots pine stand. 2. The pattern of transfer and the effects of nitrogen availability, Forestry 59 (1986) 17-27.

[36] Luxmoore R.J., Grizzard Y., Straud R.H., Nutrient translocation in the outer canopy and understory of an eastern dediduous forest, For. Sci. 27 (1981) 505-518. 
[37] Martín A., Gallardo J.F., Santa Regina I., Dinámica de la descomposición de hojas de rebollo en cuatro ecosistemas forestales de la Sierra de Gata (provincia de Salamanca, España): Indices de descomposición, Invest. Agrar. Sist. Recur. For. 2 (1993) 5-17.

[38] Martín A. Gallardo J.F., Santa Regina I., Long-term decomposition process of leaf litter from Quercus pyrenaica forest across a rainfall gradient (Spanish Central System), Ann. Sci. For. 54 (1997) 191-202.

[39] Meentemeyer V., Macroclimate and lignin control litter decomposition rates, Ecology 59 (1978) 465-472.

[40] Melillo J.M. Aber J.D., Muratore J.M., Nitrogen and lignin control of hardwood leaf litter decomposition dynamics, Ecology 63 (1982) 621-626.

[41] Millar C.S., Decomposition of coniferous leaf litter, in: Dickinson C.H. and Pug G.J.F. (Eds.), Biology of plant litter decomposition, Academic, San Diego, California, 1974, pp. 105-128.

[42) Nable R.O., Loneragan J.F., Translocation of manganese in subterranean clover (Trifolium subterraneum L. CV. Seaton Park). I. Redistribution during vegetative growth, Aus. J. Plant Physiol. 11 (1984) 101-111.

[43] Neyrinck J., Maddelein D., De Keersmaeker L., Luists N., Muys B., Biomass and nutrient cycling of a highly productive Corsican pine stand on former heathland in northern Belgium, Ann. Sci. For. 55 (1998) 389-406.

[44] Ohmann L.E., Grial D.F., Biomass distribution of unmanaged upland forests in Minnesota, For. Ecol. Manag. 13 (1985) 322-331.

[45] Olson J.S., Energy storage and the balance of producers and decomposers in ecological systems, Ecology 14 (1963) 322-331.

[46] O’Neill R.V., DeAngelis D.L., Comparative productivity and biomass relations of forest ecosystems, in: Riechle D.E. (Ed.), Dynamic properties of forest ecosystems, Cambridge Univ. Press, London, 1981, pp. 411-449.

[47] Ostman N.L., Weaver G.T., Autumnal nutrient transfer by retranslocation, leaching, and litter fall in a chesnut oak forest in southern Illinois, Can. J. For. Res. 12 (1982) 40-51.

[48] Pires A.L., Portela E., Martins A.A., Nutrient cycling in chestnut groves in the Tras-Os-Montes region, in: Romane (Ed.), Biological Criteria for sustainable development in Natural Degenerate forests of Mediterranean Europe, Montpellier, 1994, pp. 9-22.

[49] Ranger J., Bonneau M., Effects prévisibles de l'intensification de la production et des récoltes sur la fertilité, des sols de forêt. Le cycle biologique en forêt, Rev. For. Fr. 36 (1984) 93-112.

[50] Ranger J., Bonneau M., Effects prévisibles de l'intensification de la production et des récoltes sur la fertilité, des sols de forêt. Les effects de la sylviculture, Rev. For. Fr. 38 (1986) 105-123.

[51] Rapp M., Cycle de la matière organique et des éléments minéraux dans quelques écosystems mediterranéens, CNRS, Paris, 1971, 184 p.
[52] Rapp M., De Derfoufi E., Blanchard A., Productivity and nutrient uptake in a holm oak (Quercus ilex L.) stand and during regeneration after clearcut, Vegetatio 99-100 (1992) 263-272.

[53] Ryan D.F., Bormann F.H., Nutrient resorption in northern hard-wood forest, Bioscience 32 (1982) 29-32.

[54] Santa Regina I., Contribución al estudio de la dinámica de materia orgánica y bioelementos en bosques de la Sierra de Béjar. Tesis doctoral. Universidad de Salamanca, Salamanca, 1987, 464 pp.

[55] Santa Regina I., Gallardo J.F., San Miguel C., Ciclos biogeoquímicos en bosques de la Sierra de Béjar (Salamanca, España): 2. Retomo potencial de bioelementos por medio de la hojarasca, Rev. Ecol. Biol. Sol. 26 (1989a) 155-170.

[56] Santa Regina I., Gallardo J.F., San Miguel C., Ciclos biogeoquímicos en bosques de la Sierra de Béjar (Salamanca, España). 3. Descomposición de la hojarasca, Rev. Ecol. Biol. Sol. 26 (1989b) 407-416.

[57] Santa Regina I., Rapp M., Martín A., Gallardo J.F., Nutrient release dynamics in decomposing leaf litter in two Mediterranean deciduous oak species, Ann. Sci. For. 54 (1997) $747-760$.

[58] Santa Regina I., Tarazona, T., Organic matter dynamics in beech and pine stands of mountainous Mediterranean climate area, Ann. For. Sci. 56 (1999) 667-678.

[59] Satoo T., Madgwichk H.A.I., Forest Biomass, in: Nijhoff M. and Junk W. (Eds.), Forestry Sciences, London 1982, 152 p.

[60] Saur E. Ranger J., Lemoine B., Gelpe J., Micronutrient distribution in 16-year-old maritime pine - Tree, Physiology 10 (1992) 307-316.

[61] Shanks R.E., Olson J.S., First-year breakdown of leaf litter in Southern Appalachian forests, Sciences 134 (1961) 194-195.

[62] Singh K.P., Litter production and nutrient turnover in deciduous forest of Varanasi, Proc. Symp. Rec. Adv. Trop. Ecol., 1978, pp. 655-665.

[63] Staaf H., Berg B., Plant litter imput to soil, in: Clark \& Rosswall. T. (Eds.), Terrestrial nitrogen cycles, Ecol. Bull (Stockholm) 33 (1981) 147-162.

[64] Toutain F., Les humus forestiers. Structure et modes de fonctionnement, Rev. For. Fr. 33 (1981) 449-477.

[65] Tyrrell L.E., Boerner R.E.J., Larix laricina and Picea mariana: relationships among leaf life-span, foliar nutrient patterns, nutrient conservation, and growth efficiency, Can. J. Bot. 65 (1987) 1570-1577.

[66] Whittaker R.H., Niering W.A., Vegetation of the Santa Catalina mountains, Arizona. V Biomass, productivity land diversity along the elevation gradient, Ecology 56 (1975) 771-790.

[67] Woodwell G.M., Whittaker R.H., Hougton R.A., Nutrient concentrations in plants in the Brookhaven oak pine forest, Ecology 56 (1975) 318-332. 